\title{
PENGARUH MODAL, TENAGA KERJA DAN BAHAN BAKU TERHADAP PENDAPATAN PENGUSAHA INDUSTRI SANGGAH DI KECAMATAN MENGWI
}

\author{
Komang Widya Nayaka ${ }^{1}$, \\ I Nengah Kartika ${ }^{2}$ \\ ${ }^{1,2}$ Fakultas Ekonomi dan Bisnis Universitas Udayana, Bali, Indonesia \\ e-mail: nayaka.4599@yahoo.com
}

\begin{abstract}
ABSTRAK
Sebagai daerah sentra industri, Kecamatan Mengwi berpeluang mengembangkan industri sanggah lebih baik dan maju, sehingga akan berpengaruh pada tingkat penghasilan. Tujuan penelitian untuk menganalisis pengaruh modal, tenaga kerja dan bahan baku secara simultan dan parsial terhadap pendapatan pengusaha industri sanggah di Kecamatan Mengwi. Lokasi penelitian di Kecamatan Mengwi, Kabupaten Badung. Penelitian memusatkan pembahasan mengenai pendapatan pengusaha industri sanggah dan faktor-faktor yang mempengaruhinya. Metode penentuan sampel pada penelitian ini menggunakan metode Non Probability Sampling. Dengan menggunakan rumus Slovin, populasi sebanyak 132 pengusaha industri sanggah dan batas kesalahan 10 persen, maka diperoleh sampel sebanyak 57 pengusaha industri.Teknik analisis data yang digunakan untuk memecahkan permasalahan dalam penelitian yaitu teknik analisis regresi linier berganda. Hasil penelitian menunjukkan modal, tenaga kerja, dan bahan baku secara simultan berpengaruh signifikan terhadap Pendapatan pengusaha industri sanggah di Kecamatan Mengwi. Modal, tenaga kerja, dan bahan baku secara parsial berpengaruh positif dan signifikan terhadap pendapatan pengusaha industri sanggah di Kecamatan Mengwi. Hal ini berarti bahwa semakin besar modal yang dikeluarkan, tenaga kerja yang digunakan dan jumlah bahan baku yang dimiliki, maka semakin besar pula kemungkinan jumlah produk yang dihasilkan, sehingga kemungkinan pendapatan yang diterima semakin besar dari hasil penjualan produksinya.
\end{abstract}

Kata kunci : Modal, Tenaga Kerja, Bahan Baku, Pendapatan

\begin{abstract}
As the industrial center, Mengwi District has the opportunity to develop better and more advanced sanggah industry, so that it will affect the high income level. The purpose of this study is to analyze the effect of capital, labor and raw materials simultaneously and partially to the income of industrial entrepreneurs sanggah in District Mengwi.The location of this research is in District Mengwi, Badung regency. The scope of this research is carried out by focusing on the income of the sanggah industrial entrepreneurs and the factors that influence them. The method of determining the sample in this study using the method of Non Probability Sampling. By using the Slovin formula, the population of 132 industrial business entrepreneurs and error limits of 10 percent, then obtained a sample of 57 industrial entrepreneurs.Teknik data analysis used to solve problems in this study is a technique of multiple linear regression analysis.The results showed that capital, labor, and raw materials simultaneously significantly influence the income of industrial entrepreneurs sanggah in District Mengwi. Capital, labor, and raw materials partially have a positive and significant impact on the income of industrial entrepreneurs in Mengwi District. This means that the greater the capital spent, the labor used and the amount of raw materials owned, the greater the likelihood of the number of products produced, so the possibility of income received greater than the proceeds from the sale of production.
\end{abstract}

Keywords: Capital, Labor, Raw Materials, Revenue 
Komang Widya Nayaka, Pengaruh Modal, Tenaga Kerja dan Bahan Baku...

\section{PENDAHULUAN}

Pembangunan merupakan suatu upaya untuk meningkatkan kesejahteraan, yaitu berupa kegiatan-kegiatan yang dilakukan suatu negara untuk mengembangkan kegiatan ekonomi dan taraf hidup masyarakat (Arsyad, 2003). Pembangunan ekonomi yang dilaksanakan oleh negara yang sedang berkembang bertujuan meratakan pembangunan ekonomi dan hasilnya kepada seluruh masyarakat, meningkatkan laju pertumbuhan ekonomi, meningkatkan kesempatan kerja, pemerataan pendapatan, mengurangi perbedaan kemampuan antar daerah, struktur perekonomian yang seimbang (Hapsari, 2014).

Pertumbuhan ekonomi daerah diukur dengan menggunakan Produk Domestik Regional Bruto (PDRB). PDRB merupakan total atas keseluruhan nilai barang dan jasa yang diperoleh dari seluruh kegiatan perekonomian yang dilakukan di daerah dalam suatu periode tertentu. Tingkat pertumbuhan ekonomi di suatu daerah dihitung dengan PDRB atas dasar harga konstan. PDRB sebagai ukuran penting yang digunakan untuk mengukur keberhasilan pembangunan ekonomi. PDRB perkapita merupakan nilai PDRB atas dasar harga berlaku dibagi jumlah penduduk disuatu daerah (KPPOD, 2003). Untuk lebih jelasnya data data PDRB Kabupaten Badung di sajikan pada tabel berikut.

Berdasarkan Tabel 1 menunjukkan bahwa dari periode 2014-2016 Laju pertumbuhan PDRB Kabupaten Badung pada lapangan usaha industri pengolahan setiap tahunnya sektor ini mengalami penurunan. Pada Tahun 2014 yaitu 1.283.499.34 juta rupiah, Tahun 2016 menjadi 14.479,32 juta rupiah. Dilihat dari total PDRB Kabupaten Badung setiap tahunnya mengalami peningkatan. Kondisi 
ISSN : 2337-3067

E-Jurnal Ekonomi dan Bisnis Universitas Udayana 7.8 (2018): 1927-1956

ini menandakan perlunya pengembangan pada sektor industri pengolahan, untuk dapat menopang PDRB Kabupaten Badung.

Tabel 1. PDRB Dan Laju Pertumbuhan PDRB Kabupaten Badung Atas Dasar Harga Konstan 2010 Menurut Lapangan Usaha Tahun 2014 -2016.

\begin{tabular}{|c|c|c|c|c|c|c|c|}
\hline \multirow[t]{2}{*}{ No } & \multirow[t]{2}{*}{ Lapangan Usaha } & \multicolumn{2}{|l|}{2014} & \multicolumn{2}{|l|}{2015} & \multicolumn{2}{|l|}{2016} \\
\hline & & $\begin{array}{l}\text { PDRB (Juta } \\
\text { Rupiah) }\end{array}$ & $\begin{array}{l}\text { Laju } \\
(\%)\end{array}$ & $\begin{array}{l}\text { PDRB (Juta } \\
\text { Rupiah) }\end{array}$ & $\begin{array}{l}\text { Laju } \\
(\%)\end{array}$ & $\begin{array}{l}\text { PDRB (Juta } \\
\text { Rupiah) }\end{array}$ & $\begin{array}{l}\text { Laju } \\
(\%)\end{array}$ \\
\hline 1. & $\begin{array}{l}\text { Pertanian, Kehutanan, } \\
\text { dan Perikanan }\end{array}$ & $2.087 .311,52$ & 5,31 & $2.182 .148,25$ & 4,54 & $2.243 .344,23$ & 2,80 \\
\hline 2. & $\begin{array}{l}\text { Pertambangan dan } \\
\text { Penggalian }\end{array}$ & $106.351,56$ & 1,15 & $102.076,35$ & $-4,02$ & $104.234,34$ & 2,11 \\
\hline 3. & Industri Pengolahan & $1.283 .499,34$ & 10,33 & $1.387 .237,78$ & 8,08 & $14.479,32$ & 4,38 \\
\hline 4. & $\begin{array}{l}\text { Pengadaan Listrik dan } \\
\text { Gas }\end{array}$ & $59.447,24$ & 7,36 & $60.098,40$ & 1,10 & $65.577,68$ & 9,12 \\
\hline 5. & $\begin{array}{l}\text { Pengadaan Air, } \\
\text { Pengelolaan Sampah, } \\
\text { Limbah dan Daur } \\
\text { Ulang }\end{array}$ & $85.523,50$ & 8,76 & $88.569,39$ & 3,56 & $93.194,08$ & 5,22 \\
\hline 6. & Konstruksi & $2.705 .925,44$ & 3,16 & $2.817 .432,18$ & 4,12 & $3.009 .188,41$ & 6,81 \\
\hline 7. & $\begin{array}{lr}\text { Perdagangan } & \text { Besar } \\
\text { dan Eceran; Reparasi } \\
\text { Mobil dan Sepeda } \\
\text { Motor }\end{array}$ & $2.073 .019,99$ & 8,78 & $2.238 .226,30$ & 7,97 & $2.359 .245,68$ & 5,41 \\
\hline 8. & $\begin{array}{ll}\text { Transportasi } & \text { dan } \\
\text { Pergudangan } & \end{array}$ & $4.958 .177,64$ & 2,73 & $5.093 .133,81$ & 2,72 & $5.552 .875,01$ & 9,03 \\
\hline 9. & $\begin{array}{l}\text { Penyediaan } \\
\text { Akomodasi dan } \\
\text { Makan Minum }\end{array}$ & $7.132 .961,49$ & 7,57 & $7.640 .246,88$ & 7,11 & $8.142 .314,48$ & 6,57 \\
\hline 10. & $\begin{array}{ll}\text { Informasi dan } \\
\text { Komunikasi }\end{array}$ & $2.092 .927,96$ & 8,59 & $2.276 .899,04$ & 8,79 & $2.481 .239,41$ & 8,97 \\
\hline 11. & $\begin{array}{l}\text { Jasa Keuangan dan } \\
\text { Asuransi }\end{array}$ & $819.727,54$ & 11,15 & $890.634,57$ & 8,65 & $957.430,07$ & 7,50 \\
\hline 12. & Real Estat & $1.115 .698,20$ & 10,45 & $1.202 .303,50$ & 7,76 & $1.264 .178,17$ & 5,15 \\
\hline 13. & Jasa Perusahaan & $220.511,43$ & 9,12 & $236.098,87$ & 7,07 & $248.113,39$ & 5,09 \\
\hline 14. & $\begin{array}{l}\text { Administrasi } \\
\text { Pemerintahan, } \\
\text { Pertahanan dan } \\
\text { Jaminan Sosial Wajib }\end{array}$ & $1.122 .021,42$ & 12,43 & $1.229 .680,24$ & 9,60 & $1.324 .152,76$ & 7,68 \\
\hline 15. & Jasa Pendidikan & $981.167,07$ & 12,30 & $1.062 .447,70$ & 8,28 & $1.137 .383,71$ & 7,05 \\
\hline 16. & $\begin{array}{l}\text { Jasa Kesehatan dan } \\
\text { Kegiatan Sosial }\end{array}$ & $391.441,84$ & 14,12 & $432.650,18$ & 10,53 & $468.674,44$ & 8,33 \\
\hline 17. & Jasa lainnya & $222.346,90$ & 9,33 & $240.595,96$ & 8,21 & $261.506,73$ & 8,69 \\
\hline PDF & & $27.458 .060,08$ & 6,98 & $29.180 .479,41$ & 6,27 & $31.160 .584,59$ & 6,79 \\
\hline
\end{tabular}

Sumber : Badan Pusat Statistik 2017

Kecamatan Mengwi terletak pada wilayah pengembangan Kabupaten Badung bagian tegah, yang menjadi pusat pengembangan industri kecil dan 
Komang Widya Nayaka, Pengaruh Modal, Tenaga Kerja dan Bahan Baku...

Rumah Tangga. Data mengenai perkembangan jumlah industri pengolahan yang ada di Kecamatan Mengwi di sajikan pada Tabel 2.

Tabel 2. Jumlah Perusahaan Industri Menurut Jenis (unit) dan Jumlah Tenaga Kerja (orang) di Kecamatan Mengwi Tahun 2016.

\begin{tabular}{|c|c|c|c|c|c|c|c|c|c|c|c|}
\hline \multirow[t]{2}{*}{ No } & \multirow[t]{2}{*}{ Desa/Kelurahan } & \multicolumn{2}{|l|}{ Besar } & \multicolumn{2}{|l|}{ Sedang } & \multicolumn{2}{|l|}{ Kecil } & \multicolumn{2}{|c|}{ Kerajinan } & \multicolumn{2}{|c|}{ Jumlah } \\
\hline & & $\begin{array}{l}\text { Unit } \\
\text { usaha }\end{array}$ & TK & $\begin{array}{l}\text { Unit } \\
\text { usaha }\end{array}$ & TK & $\begin{array}{l}\text { Unit } \\
\text { usaha }\end{array}$ & TK & $\begin{array}{l}\text { Unit } \\
\text { usaha }\end{array}$ & TK & $\begin{array}{l}\text { Unit } \\
\text { usaha }\end{array}$ & TK \\
\hline 1. & Cemagi & - & - & - & - & 14 & 52 & 44 & 176 & 58 & 228 \\
\hline 2. & Munggu & - & - & 1 & 76 & 24 & 43 & 58 & 142 & 88 & 194 \\
\hline 3. & Pererenan & - & - & - & - & 12 & 52 & 8 & 8 & 21 & 62 \\
\hline 4. & Tumbak Bayuh & - & - & - & - & 15 & 56 & 14 & 28 & 30 & 88 \\
\hline 5. & Buduk & - & - & 1 & 32 & 62 & 120 & 36 & 84 & 98 & 241 \\
\hline 6. & Abianbase & - & - & 4 & 95 & 98 & 204 & 95 & 285 & 197 & 593 \\
\hline 7. & Sempidi & - & - & 1 & 70 & 82 & 140 & 61 & 122 & 144 & 322 \\
\hline 8. & Sading & - & - & - & - & 40 & 133 & 74 & 162 & 127 & 308 \\
\hline 9. & Lukluk & 1 & 140 & 1 & 30 & 56 & 135 & 75 & 112 & 133 & 455 \\
\hline 10. & Kapal & - & - & - & - & 161 & 707 & 186 & 465 & 345 & $\begin{array}{l}1 \\
170\end{array}$ \\
\hline 11. & Kekeran & - & - & - & - & 54 & 169 & 11 & 22 & 65 & 218 \\
\hline 12. & Mengwitani & - & - & - & - & 95 & 258 & 65 & 227 & 160 & 512 \\
\hline 13. & Mengwi & - & - & - & - & 64 & 240 & 132 & 208 & 206 & 468 \\
\hline 14. & Gulingan & - & - & - & - & 29 & 103 & 36 & 62 & 65 & 165 \\
\hline 15. & Penarungan & - & - & 1 & 20 & 27 & 94 & 72 & 209 & 117 & 353 \\
\hline 16. & Baha & - & - & 1 & 21 & 34 & 53 & 32 & 84 & 67 & 217 \\
\hline 17. & Werdi Bhuana & 1 & 111 & - & - & 39 & 102 & 24 & 49 & 64 & 294 \\
\hline 18. & Sobangan & - & - & - & - & 32 & 72 & 102 & 105 & 154 & 217 \\
\hline 19. & Sembung & - & - & - & - & 43 & 91 & 59 & 177 & 102 & 268 \\
\hline 20. & Kuwum & - & - & - & - & 16 & 24 & 23 & 33 & 39 & 67 \\
\hline JUN & LAH & 2 & 251 & 10 & 344 & 997 & $\begin{array}{l}2 \\
902\end{array}$ & 1207 & $\begin{array}{l}2 \\
760\end{array}$ & 2280 & $\begin{array}{l}6 \\
450\end{array}$ \\
\hline
\end{tabular}

\section{Sumber : Badan Pusat Statistik 2017}

Berdasarkan Tabel 2 maka dapat dilihat bahwa jumlah perusahaan yang ada di Kecamatan Mengwi pada tahun 2016 adalah sebanyak 2.280 unit yang terdiri atas 2 unit usaha besar, 10 unit usaha sedang, 997 unit usaha kecil dan 1.207 unit usaha kerajinan rumah tangga. Penyerapan tenaga kerja dari adanya industri pengolahan ini mencapai 6.450 orang. Jumlah unit usaha terbanyak di Mengwi adalah Kelurahan Kapal, yang didominasi oleh jenis usaha kecil. Berdasarkan Tabel 3 menunjukkan bahwa jumlah industri kerajinan di Kecamatan 
Mengwi mencapai 1.131 unit, yang didominasi oleh Kelurahan Kapal yaitu terdapat 158 unit industri.

Tabel 3 Jumlah Industri Kerajinan dan Tenaga kerja per Desa / Kelurahan di Kecamatan Mengwi tahun 2016.

\begin{tabular}{|c|c|c|c|}
\hline No. & Desa/Kelurahan & Industri Kerajinan & Tenaga Kerja \\
\hline 1. & Cemagi & 96 & 228 \\
\hline 2. & Munggu & 60 & 135 \\
\hline 3. & Pererenan & 20 & 41 \\
\hline 4. & Tumbak Bayuh & 10 & 19 \\
\hline 5. & Buduk & 25 & 56 \\
\hline 6. & Abianbase & 95 & 301 \\
\hline 7. & Sempidi & 56 & 104 \\
\hline 8. & Sading & 83 & 167 \\
\hline 9. & Lukluk & 75 & 134 \\
\hline 10. & Kapal & 158 & 398 \\
\hline 11. & Kekeran & 7 & 12 \\
\hline 12. & Mengwitani & 42 & 168 \\
\hline 13. & Mengwi & 123 & 228 \\
\hline 14. & Gulingan & 5 & 15 \\
\hline 15. & Penarungan & 82 & 202 \\
\hline 16. & Baha & 19 & 68 \\
\hline 17. & Werdi Bhuana & 12 & 38 \\
\hline 18. & Sobangan & 112 & 145 \\
\hline 19. & Sembung & 51 & 156 \\
\hline 20. & Kuwum & - & - \\
\hline & Kecamatan Mengwi & 1131 & 2615 \\
\hline
\end{tabular}

\section{Sumber : Disperindag Kabupaten Badung 2017}

Tingginya permintaan lapangan pekerjaan akibat pertumbuhan penduduk yang mengalami peningkatan, sektor industri menjadi penyerap tenaga kerja terbanyak. Kondisi ini merupakan peluang yang membuka kemungkinan segala bidang usaha dapat memberikan pengaruh pada perekonomian di suatu daerah. Seperti salah satu bidang usaha di Kecamatan Mengwi yaitu industri kerajinan sanggah yang disajikan pada tabel 4. 
Tabel 4 Jumlah Industri Sanggah di Masing masing Desa / Kelurahan Kecamatan Mengwi (unit) Tahun 2016.

\begin{tabular}{|c|c|c|}
\hline No. & Desa/Kelurahan & Jumlah \\
\hline 1. & Cemagi & - \\
\hline 2. & Munggu & 6 \\
\hline 3. & Pererenan & 2 \\
\hline 4. & Tumbak Bayuh & 1 \\
\hline 5. & Buduk & 2 \\
\hline 6. & Abianbase & 16 \\
\hline 7. & Sempidi & 4 \\
\hline 8. & Sading & 2 \\
\hline 9. & Lukluk & 8 \\
\hline 10. & Kapal & 55 \\
\hline 11. & Kekeran & 7 \\
\hline 12. & Mengwitani & 10 \\
\hline 13. & Mengwi & 8 \\
\hline 14. & Gulingan & - \\
\hline 15. & Penarungan & 3 \\
\hline 16. & Baha & - \\
\hline 17. & Werdi Bhuana & 5 \\
\hline 18. & Sobangan & 2 \\
\hline 19. & Sembung & 1 \\
\hline 20. & Kuwum & - \\
\hline & camatan Mengwi & 132 \\
\hline
\end{tabular}

\section{Sumber : Kecamatan Mengwi 2017}

Pada Tabel 4 menunjukan jumlah usaha industri sanggah yang terdapat pada Kecamatan Mengwi, dengan jumlah industri sanggah terbanyak pada Desa Kapal dengan jumlah 55 unit dari 132 unit industri sanggah.

Sebagai daerah sentra industri, Kecamatan Mengwi berpeluang untuk bisa mengembangkan industri sanggah lebih baik dan lebih maju, sehingga akan berpengaruh pada tingkat penghasilan yang tinggi. Terdapat beberapa kendala dalam usaha memajukan industri ini baik kendala bersifat intern ataupun ekstern (Parinduri, 2016). Menurut Edogbanya (2013), jalur distribusi barang dan jasa ditingkat bawah industri ini diharapkan dapat lebih memeratakan perekonomian pada masyarakat menengah kebawah yang menjadi permasalahan pada negara- 
negara berkembang. Keberadaan industri ini di Kecamatan Mengwi, Kabupaten Badung menjadi ujung tombak pemasaran yang potensial sehingga akan menciptakan pembangunan ekonomi yang merata. Pengembangan industri ini merupakan suatu cara yang cukup baik untuk dapat mengatasi permasalahan ketimpangan pendapatan dan pertumbuhan ekonomi antar wilayah di suatu daerah (Hae-Young Lee, 2013).

Modal merupakan salah satu faktor produksi dalam suatu kegiatan usaha. Tanpa modal usaha tidak akan dapat berjalan (Asri, 1985). Untuk dapat memenuhi kewajiban terhadap tenaga kerja, pengusaha harus memberikan upah yang diperoleh dari modal untuk membayarnya. Sumber dari modal usaha itu dapat bersumber dari modal sendiri dan modal dari luar, dimana modal harus dimaksimalkan dengan baik kegunaannya (Zhou Gideon, 2013). Modal merupakan kebutuhan yang kompleks karena berhubungan dengan keputusan pengeluaran dalam kegiatan usaha untuk meningkatkan pendapatan dan mencapai keuntungan yang maksimum (Priyandika, 2015). Modal yang dimiliki pengusaha sektor informal relatif sedikit sehingga itu akan sulit untuk dapat meningkatkan produktivitasnya.

Kurangnya modal dapat menyebabkan usaha di sektor ini sulit untuk berkembang (Widodo, 2005). Modal yang merupakan salah satu faktor produksi akan menentukan produktivitas perusahaan yang berdampak terhadap pendapatan perusahaan. Teori Cobb-douglas yang menyatakan bahwa modal mempengaruhi output produksi. Kondisi ini menunjukkan semakin tinggi modal akan dapat meningkatkan hasil produksi, karena dalam proses produksi membutuhkan biaya 
Komang Widya Nayaka, Pengaruh Modal, Tenaga Kerja dan Bahan Baku...

yang digunakan untuk tenaga kerja dan pembelian bahan baku serta peralatan (Sulistiana, 2013). Modal dan tenaga kerja meningkat maka produktivitas dan pendapatan juga akan meningkat (Frabdorf, 2008).

Tenaga kerja merupakan faktor yang sangat penting dalam produksi, karena tenaga kerja merupakan faktor penggerak faktor input yang lain, tanpa adanya tenaga kerja maka faktor produksi lain tidak akan berarti. Dengan meningkatnya produktifitas tenaga kerja akan mendorong peningkatan produksi sehingga pendapatan pun akan ikut meningkat. Menurut Sumarsono (2013) apabila banyak produk yang terjual dengan demikian pengusaha akan meningkatkan jumlah produksinya. Meningkatnya jumlah produksi akan mengakibatkan meningkatnya tenaga kerja yang dibutuhkan, sehingga dengan demikian pedapatan juga akan meningkat.

Bahan baku juga merupakan faktor penting yang mempengaruhi pendapatan. Bahan baku merupakan faktor produksi yang dibutuhkan dalam setiap proses produksi, semakin besar jumlah bahan baku yang dimiliki, maka semakin besar pula kemungkinan jumlah produk yang dihasilkan, sehingga kemungkinan pendapatan yang diterima semakin besar dari hasil penjualan produksinya. Bahan baku merupakan jumlah bahan yang diperlukan untuk melaksanakan proses produksi dalam jangka waktu tertentu (Siswanta, 2011). Persediaan bahan baku di dalam perusahaan merupakan hal yang sangat penting untuk dikendalikan dengan baik, sehingga perusahaan dapat menghasilkan pendapatan yang optimal. 
Dilihat dari segi usaha pengembangan produk-produk industri lokal dan dari segi penyerapan tenaga kerja itu sejalan dengan pembangunan daerah dan peningkatan kesejahteraan masyarakat. Berdasarkan observasi awal yang dilakukan terjadi banyak kendala yang dihadapai seperti kekurangan modal, keterbatasan SDM dan bahan baku yang semakin terbatas, serta masih terjadi ketimpangan pendapatan antar industri sanggah di Kecamatan Mengwi. Mengingat Kecamatan Mengwi salah satu Kecamatan yang berada di wilayah pengembangan sektor industri pengolahan Kabupaten Badung, serta menjadi suatu fenomena yang harus diperhatikan lebih lanjut, maka tujuan penelitian ini adalah untuk menganalisis pengaruh modal, tenaga kerja dan bahan baku secara simultan dan secara parsial terhadap pendapatan pengusaha industri sanggah di Kecamatan Mengwi.

\section{METODE PENELITIAN}

Lokasi penelitian ini adalah di Kecamatan Mengwi, Kabupaten Badung. Ruang lingkup penelitian ini dilaksanakan dengan memusatkan pembahasan mengenai pendapatan pengusaha industri sanggah dan faktor-faktor yang mempengaruhinya. Objek penelitian ini adalah modal, tenaga kerja, bahan baku dan pendapatan pengusaha industri sanggah di Kecamatan Mengwi.

Jenis data yang digunakan dalam penelitian ini adalah data kuantitatif dan kualitatif. Data kuantitatif yang digunakan dalam penelitian ini adalah data modal, tenaga kerja bahan baku dan pendapatan pengusaha industri sanggah di 
Komang Widya Nayaka, Pengaruh Modal, Tenaga Kerja dan Bahan Baku...

Kecamatan Mengwi. Data kualitatifnya adalah data mengenai gambaran umum lokasi penelitian dan data lainnya yang terkait dengan penelitian ini.

Berdasarkan sumbernya data dalam penelitian ini terdiri dari, yaitu data primer dan data sekunder. Data primer dikumpulkan sendiri oleh peneliti langsung dari sumber pertama atau tempat penelitian dilakukan melalui kuesioner dan wawancara. Data sekunder adalah data yang dikumpulkan dan dipublikasikan oleh pihak lain. Data sekunder yang digunakan dalam penelitian ini diperoleh dari Badan Pusat Statistik atau instansi terkait lainnya.

Responden dalam penelitian ini adalah pemilik usaha industri sanggah di Kecamatan Mengwi, Kabupaten Badung. Pengambilan jumlah sampel penelitian di masing-masing desa ditentukan dengan menggunakan metode proportional stratified random sampling. Dengan demikian jumlah sampel pengusaha industri sanggah di Kecamatan Mengwi adalah sebanyak 57 orang.

Teknik analisis yang digunakan untuk mengetahui arah hubungan antara variabel modal, tenaga kerja dan bahan baku, dengan variabel pendapatan yaitu menggunakan analisis regresi liner berganda, dengan persamaan struktur yang digunakan adalah sebagai berikut :

$$
\mathrm{Y}_{\mathrm{i}}=\beta_{0}+\beta_{1} \mathrm{X}_{1 \mathrm{i}}+\beta_{2} \mathrm{X}_{2 \mathrm{i}}+\beta_{3} \mathrm{X}_{3 \mathrm{i}}+\mu_{\mathrm{i}}
$$

Keterangan:

$$
\begin{array}{ll}
\mathrm{Y}_{\mathrm{i}} & =\text { Pendapatan } \\
\mathrm{X}_{1 \mathrm{i}} & =\text { Modal } \\
\mathrm{X}_{2 \mathrm{i}} & =\text { Tenaga Kerja } \\
\mathrm{X}_{3 \mathrm{i}} & =\text { Bahan Baku } \\
\beta_{1,}, \beta_{2}, \beta_{3} & =\text { koefisien Regresi } \\
\beta_{0} & =\text { konstanta/ intersep } \\
\mu_{\mathrm{i}} & =\text { pengganggu }
\end{array}
$$




\section{HASIL DAN PEMBAHASAN}

\section{Gambaran Umum Daerah Penelitian}

Secara geografis Kecamatan Mengwi terdiri dari dataran rendah dengan ketinggian $150 \mathrm{M}$ dari permukaan laut. Dilihat dari luas Kecamatannya, Kecamatan Mengwi Memiliki luas 82,00 km2. Batas-batas wilayah Kecamatan Mengwi yaitu bagian utara berbatasan dengan Kecamatan Baturiti, Kabupaten Tabanan. Batas wilayah Mengwi bagian timur berbatasan dengan Kecamatan Abiansemal. Batas wilayah Mengwi bagian barat berbatasan dengan Kecamatan Kediri, Kabupaten Tabanan. Jumlah penduduk Kecamatan Mengwi dari tahun ke tahun terus mengalami peningkatan, penyebabnya adalah banyaknya urbanisasi penduduk baik dari luar Bali yang mencari mata pencaharian.

\section{Karakteristik Responden}

Pengusaha industri sanggah di Kecamatan Mengwi yang menjadi objek dalam penelitian ini adalah sebanyak 57 orang. Kelompok responden berdasarkan umur ditunjukan pada Tabel 5 berikut.

\section{Tabel 5 Jumlah Responden Pengusaha Industri sanggah di Kecamatan Mengwi Berdasarkan Kelompok Umur}

\begin{tabular}{cccc}
\hline No. & $\begin{array}{c}\text { Kelompok Umur } \\
\text { (Tahun) }\end{array}$ & \multicolumn{2}{c}{ Jumlah Responden } \\
\cline { 3 - 4 } $\mathbf{1}$ & $31-35$ & 8 & Persentase (\%) \\
\hline $\mathbf{2}$ & $36-40$ & 9 & 14,0 \\
\hline $\mathbf{3}$ & $41-45$ & 14 & 15,8 \\
\hline $\mathbf{4}$ & $46-50$ & 12 & 24,6 \\
\hline $\mathbf{5}$ & $51-55$ & 11 & 21,1 \\
\hline $\mathbf{6}$ & $56-60$ & 3 & 19,3 \\
\hline & Jumlah & $\mathbf{5 7}$ & 5,3 \\
\hline
\end{tabular}

Sumber : Data Primer Diolah, 2017 
Komang Widya Nayaka, Pengaruh Modal, Tenaga Kerja dan Bahan Baku...

Tabel 5 menunjukkan bahwa keberhasilan seorang pengusaha industri sanggah di Kecamatan Mengwi memang membutuhkan waktu yang cukup lama dikarenakan semua kegiatan bisnis atau produksi harus ada perbaikan dan pembenahan dalam industri tersebut, maka dari itu sebagian besar dari pengusaha memiliki umur 41-45 tahun yang dapat dikatakan kelompok usia tua.

Jenis kelamin menjadikan faktor yang berkaitan dengan kemampuan pengusaha industri sanggah dalam menjalankan suatu usahanya. Mengenai data berdasarkan jenis kelamin pada industri sanggah di Kecamatan Mengwi dapat dilihat pada Tabel 6 berikut.

Tabel 6 Jumlah Responden Pengusaha Industri sanggah di Kecamatan Mengwi Berdasarkan Jenis Kelamin

\begin{tabular}{llcc}
\hline No. & Jenis Kelamin & \multicolumn{2}{c}{ Jumlah Responden } \\
\cline { 3 - 4 } & & Orang & Persentase (\%) \\
\hline $\mathbf{1}$ & Laki-laki & 50 & 87,7 \\
\hline $\mathbf{2}$ & Perempuan & 7 & 12,3 \\
\hline & Jumlah & 57 & 100 \\
\hline
\end{tabular}

Sumber : Data Primer Diolah, 2017

Tabel 6 menunjukan bahwa jumlah pengusaha industri sanggah dengan jenis kelamin laki-laki lebih berperan di bandingkan jenis kelamin wanita dalam menjalankan usaha industri sanggah di Kecamatan Mengwi, dikarenakan tingkat pendidikan, pengalaman dan jiwa kewirausahaan yang dimiliki pada jenis kelamin laki-laki dominan lebih tinggi.

Dilihat dari tingkat pendidikan responden pengusaha industri sanggah di Kecamatan Mengwi mulai dari tingkat SD, SMP, SMA dan Sarjana. Tabel 7 berikut memaparkan jumlah responden pengusaha industri sanggah di Kecamatan Mengwi berdasarkan tingkat pendidikan. 
Tabel 7 Jumlah Responden Pengusaha Industri sanggah di Kecamatan Mengwi Berdasarkan Tingkat Pendidikan

\begin{tabular}{llcc}
\hline \multirow{2}{*}{ No. } & Tingkat pendidikan & \multicolumn{2}{c}{ Jumlah Responden } \\
\cline { 3 - 4 } & & Orang & Persentase (\%) \\
\hline $\mathbf{1}$ & SD & 10 & 17,5 \\
\hline $\mathbf{2}$ & SMP & 13 & 22,8 \\
\hline $\mathbf{3}$ & SMA & 28 & 49,1 \\
\hline $\mathbf{4}$ & Perguruan Tinggi & 6 & 10,5 \\
\hline & Jumlah & $\mathbf{5 7}$ & $\mathbf{1 0 0}$ \\
\hline
\end{tabular}

Sumber : Data Primer Diolah, 2017

Berdasarkan Tabel 7 menunjukan bahwa jenjang pendidikan pada pengusaha industri sanggah di Kecamatan Mengwi paling banyak adalah lulusan SMA yaitu sejumlah 28 orang dengan persentase 49,1 persen. Rendahnya tingkat pendidikan menjadi kendala dalam menjalani usahanya, dimana tinggi rendahnya tingkat pendidikan menjadi faktor yang sangat penting dalam menjalankan proses produksi, namun dari rendahnya tingkat pendidikan belum menjamin keberhasilan atau kesuksesan pelaku usaha yang masih banyak didorong faktor lain seperti banyaknya relasi yang dimiliki pelaku usaha tersebut dalam menciptakan efisiensi produksi dan meningkatkan daya saing dalam pasar global.

Tabel 8 Jumlah Responden Pengusaha Industri Sanggah di Kecamatan Mengwi Berdasarkan Pendapatan Per Bulan

\begin{tabular}{cccc}
\hline \multirow{2}{*}{ No. } & Pendapatan $(\mathbf{R p})$ & \multicolumn{2}{c}{ Jumlah Responden } \\
\cline { 3 - 4 } & & Pengusaha & Persentase (\%) \\
\hline $\mathbf{1}$ & $<10.000 .000$ & 2 & 3,5 \\
\hline $\mathbf{2}$ & $10.000 .000-20.000 .000$ & 16 & 28,1 \\
\hline $\mathbf{3}$ & $20.000 .000-30.000 .000$ & 9 & 15,8 \\
\hline $\mathbf{4}$ & $30.000 .000-40.000 .000$ & 5 & 8,8 \\
\hline $\mathbf{5}$ & $40.000 .000-50.000 .000$ & 8 & 14,0 \\
\hline $\mathbf{6}$ & $>50.000 .000$ & 17 & 29,8 \\
\hline & Jumlah & $\mathbf{5 7}$ & $\mathbf{1 0 0}$ \\
\hline
\end{tabular}

Sumber : Data Primer Diolah, 2017 
Komang Widya Nayaka, Pengaruh Modal, Tenaga Kerja dan Bahan Baku...

Tabel 8 menunjukan bahwa pendapatan yang diperoleh pengusaha industri sanggah di Kecamatan Mengwi yang paling tinggi mencapai lebih dari Rp. 50.000.000 sebanyak 17 unit usaha dengan persentase sebesar 29,8 persen. Sedangkan yang paling rendah pendapatan yang diperoleh pengusaha industri sanggah di Kecamatan Mengwi adalah kurang dari Rp. 10.000.000 sebanyak 2 unit dengan persentase sebesar 3,5 persen. Hal ini menunjukkan bahwa cukup banyak konsumen yang tertarik terhadap sanggah yang di produksi oleh pengusaha industri sanggah di Kecamatan Mengwi, sehingga para pengusaha dapat memperoleh pendapatan yang cukup tinggi setiap bulannya.

Dalam penelitian ini modal dimaksud adalah asset yang berupa pembelian peralatan produksi dan untuk membiayai perbaikan tersebut untuk menghasilkan suatu barang yaitu sanggah. Tabel 9 berikut menunjukkan jumlah pengusaha industri sanggah di Kecamatan Mengwi berdasarkan besarnya modal yang digunakan.

Tabel 9 Jumlah Responden Pengusaha Industri Sanggah di Kecamatan Mengwi Berdasarkan Modal yang digunakan

\begin{tabular}{llcc}
\hline No. & Modal $(\mathbf{R p})$ & \multicolumn{2}{c}{ Jumlah Responden } \\
\cline { 3 - 4 } & & Pengusaha & Persentase \\
\hline $\mathbf{1}$ & $1.000 .000-2.500 .000$ & 21 & 36,8 \\
\hline $\mathbf{2}$ & $2.500 .000-5.000 .000$ & 24 & 42,1 \\
\hline $\mathbf{3}$ & $>5.000 .000$ & 12 & 21,1 \\
\hline & Jumlah & $\mathbf{5 7}$ & $\mathbf{1 0 0}$ \\
\hline
\end{tabular}

Sumber : Data Primer Diolah, 2017

Tabel 9 menunjukkan bahwa modal yang digunakan pengusaha industri sanggah di Kecamatan Mengwi tertinggi berada pada nilai Rp. 2.500.000 hingga Rp. 5.000.000 yakni sebanyak 24 unit usaha dengan persentase sebesar 42,10 persen. Sedangkan yang paling rendah modal digunakan lebih dari Rp. 5.000.000 
dengan jumlah usaha sebanyak 12 unit dengan persentase sebesar 21,1 persen. Industri sanggah yang ada di Kecamatan Mengwi sebagian besar modal yang digunakan dari modal sendiri dan terdapat juga sebagian pengusaha mendapat modal dari pinjaman Bank atau LPD.

Jumlah pengusaha industri sanggah di Kecamatan Mengwi berdasarkan tenaga kerja yang di serap dapat dilihat pada tabel 10 sebagai berikut.

\section{Tabel 10 Jumlah Responden Pengusaha Industri Sanggah di Kecamatan} Mengwi Berdasarkan Tenaga Kerja yang digunakan

\begin{tabular}{cccc}
\hline No. & Tenaga Kerja & \multicolumn{2}{c}{ Jumlah Responden } \\
\cline { 3 - 4 } & & Pengusaha & Persentase \\
\hline $\mathbf{1}$ & $1-4$ orang & 40 & 70,2 \\
\hline $\mathbf{2}$ & $5-8$ orang & 12 & 21,1 \\
\hline $\mathbf{3}$ & $>8$ orang & 5 & 8,8 \\
\hline & Jumlah & $\mathbf{5 7}$ & $\mathbf{1 0 0}$ \\
\hline
\end{tabular}

Sumber : Data Primer Diolah, 2017

Tabel 10 menjelaskan bahwa jumah tenaga kerja yang digunakan dari industri sanggah di Kecamatan Mengwi paling banyak diantara 1 hingga 4 orang dengan persentase 70,2 persen, sedangkan penggunaan tenaga kerja yang paling sedikit hanya terdapat pada 5 unit usaha dengan tenaga kerja yang digunakan sebanyak lebih dari 8 orang dengan persentase 8,8 persen. Hal ini menunjukan bahwa dalam menjalankan usahanya, para pengusaha industri sanggah menggunakan beberapa tenaga kerja, sehingga dapat mendukung berjalannya suatu produksi sanggah.

Bahan baku juga merupakan faktor penting yang mempengaruhi pendapatan. Semakin besar jumlah bahan baku yang dimiliki, maka semakin besar pula kemungkinan jumlah produk yang dihasilkan, sehingga kemungkinan pendapatan yang diterima semakin besar dari hasil penjualan produksinya. Berikut 
Komang Widya Nayaka, Pengaruh Modal, Tenaga Kerja dan Bahan Baku...

ini jumlah responden pengusaha sanggah di Kecamatan Mengwi berdasarkan bahan baku yang dilihat dari nilai bahan bakunya pada tabel 11 .

Tabel 11 Jumlah Responden Pengusaha Industri Sanggah di Kecamatan Mengwi Berdasarkan Bahan Baku

\begin{tabular}{cccc}
\hline No. & Bahan Baku (Rp) & \multicolumn{2}{c}{ Jumlah Responden } \\
\cline { 2 - 4 } & & Pengusaha & Persentase \\
\hline $\mathbf{1}$ & $1.000 .000-5.000 .000$ & 36 & 63,2 \\
\hline $\mathbf{2}$ & $5.000 .000-10.000 .000$ & 14 & 24,6 \\
\hline $\mathbf{3}$ & $10.000 .000-15.000 .000$ & 4 & 7,0 \\
\hline $\mathbf{4}$ & $>15.000 .000$ & 3 & 5,3 \\
\hline & Jumlah & $\mathbf{5 7}$ & $\mathbf{1 0 0}$ \\
\hline
\end{tabular}

Berdasarkan data pada Tabel 11 bahan baku yang terbesar digunakan berada pada nilai Rp. 1.000.000 hingga Rp. 5.000.000 dengan 36 unit usaha dengan tingkat persentase 63,2 persen, sedangkan yang paling sedikit nilai bahan baku yang digunakan oleh pengusaha industri sanggah adalah lebih dari Rp. 15.000.000 yaitu sebanyak 3 unit usaha dengan tingkat persentase sebesar 5,3 persen.

Langkah pertama yang perlu dilakukan untuk mengetahui bagaimana gambaran umum data yang telah dikumpulkan dari responden adalah analisis deskriptif yang disajikan dalam Tabel 12 sebagai berikut.

Tabel 12 Statistik Deskriptif

\begin{tabular}{lcrrrr}
\hline & N & \multicolumn{1}{c}{ Minimum } & Maximum & \multicolumn{1}{c}{ Mean } & Std. Deviation \\
\hline Modal & 57 & 1000000 & 8500000 & 3432500 & 1769090 \\
\hline Tenaga Kerja & 57 & 1 & 10 & 4 & 2 \\
\hline Bahan Baku & 57 & 1800000 & 38000000 & 6488200 & 6774280 \\
\hline Pendapatan & 57 & 7200000 & 135000000 & 45331000 & 34360100 \\
\hline Valid N (listwise) & 57 & & & & \\
\hline
\end{tabular}

Sumber: Data Primer Diolah, 2017.

Pengusaha industri sanggah di Kecamatan Mengwi memiliki rata-rata modal sebesar Rp. 3.432.500. Modal paling rendah (minimum) adalah sebesar Rp.1.000.000 dan modal yang paling tinggi (maksimum) adalah sebesar Rp. 
8.500.000. Pengusaha industri sanggah di Kecamatan Mengwi rata-rata memiliki jumlah tenaga kerja sebanyak 4 orang. Jumlah tenaga kerja paling sedikit yang digunakan sebanyak 1 orang dan yang paling banyak adalah 10 orang.

Total bahan baku yang digunakan pengusaha industri sanggah di Kecamatan Mengwi rata-rata sejumlah Rp. 6.488.200. Total bahan baku paling rendah (minimum) yang digunakan adalah sebesar Rp. 1.800 .000 dan paling besar adalah Rp. 3.800.000. Kemudian pendapatan pengusaha industri sanggah di Kecamatan Mengwi rata-rata sebesar Rp. 45.331.000. Pendapatan paling rendah (minimum) yang diperoleh sebesar Rp. 7.200.000 dan Pendapatan yang paling tinggi (maksimum) adalah sebesar Rp. 135.000.000 per bulan.

Pengujian data dalam penelitian ini menggunakan teknik analisis regresi linier berganda. Perhitungan koefisien regresi linier berganda dilakukan dengan analisis regresi melalui software SPSS 18.0 for Windows, diperoleh hasil yang ditunjukan pada Tabel 13 berikut :

Tabel 13 Hasil Analisis Regresi Linier Berganda

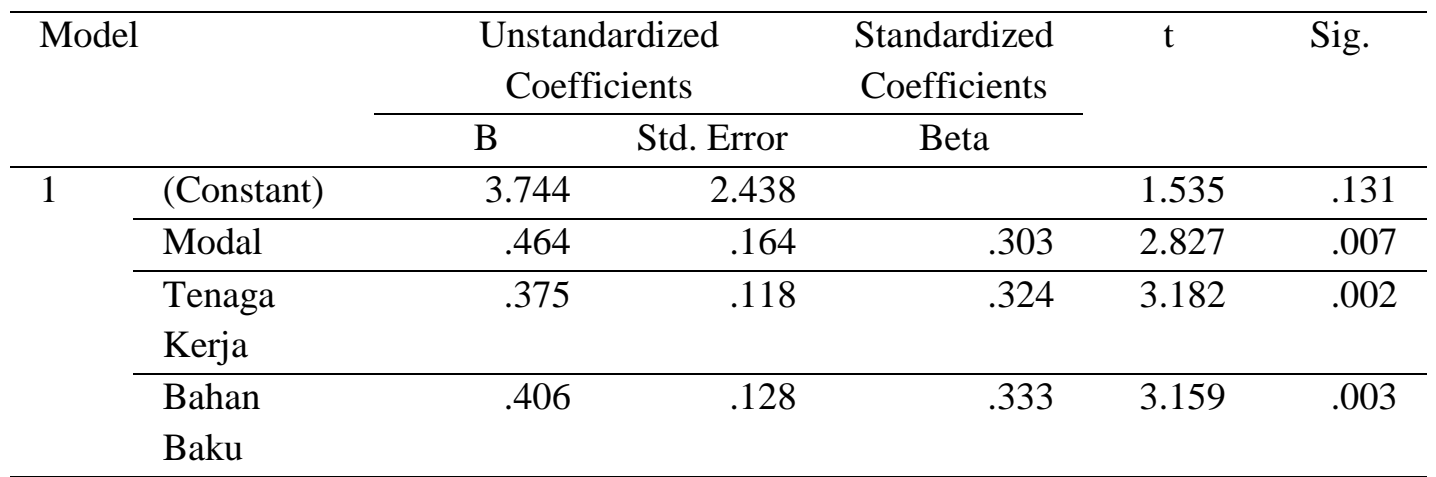

Sumber : Data Primer Diolah, 2017.

Berdasarkan hasil analisis regresi linier berganda seperti yang disajikan pada Tabel 13, maka dapat dibentuk persamaan struktural sebagai berikut : 
Komang Widya Nayaka, Pengaruh Modal, Tenaga Kerja dan Bahan Baku...

$$
Y^{\wedge}=3,744+0,464 X 1+0,375 X 2+0,406 X 3
$$

Pengujian hipotesis yang pertama yaitu "diduga bahwa modal, tenaga kerja dan bahan baku secara simultan berpengaruh signifikan terhadap pendapatan pengusaha industri sanggah di Kecamatan Mengwi” dilakukan dengan regresi uji simultan atau uji $\mathrm{F}$, dengan hasil $\mathrm{F}_{\text {hitung }}(233,896)>\mathrm{F}_{\text {tabel }}(2,78)$ atau nilai signifikasi $0,000<0,05$, maka $\mathrm{H}_{0}$ ditolak dan $\mathrm{H}_{1}$ diterima. Ini berarti bahwa modal $\left(\mathrm{X}_{1}\right)$, tenaga kerja $\left(\mathrm{X}_{2}\right)$, dan bahan baku $\left(\mathrm{X}_{3}\right)$ secara simultan berpengaruh signifikan tehadap pendapatan pengusaha industri sanggah di Kecamatan Mengwi (Y).

Besarnya pengaruh ke tiga variabel bebas dapat diketahui dengan koefisien determinasi atau Adjusted $\mathrm{R}$ square $\left(\mathrm{R}^{2}\right)=0,575$ mempunyai arti bahwa 57,5 persen pendapatan yang dihasilkan pengusaha industri sanggah di Kecamatan Mengwi dipengaruhi oleh modal, tenaga kerja dan bahan baku, sedangkan sisanya 42,5 persen dipengaruhi faktor lain yang tidak dimasukan dalam variabel penelitian. Jadi, hipotesis pertama yang diajukan, yang menyatakan bahwa modal, tenaga kerja dan bahan baku secara simultan berpengaruh signifikan terhadap pendapatan pengusaha industri sanggah di Kecamatan Mengwi diterima.

Berdasarkan hasil analisis pengaruh modal terhadap pendapatan diperoleh nilai Signifikansi sebesar $0,007<0,05$ dengan $t_{\text {hitung }}=2,827>1,674$. Modal secara parsial berpengaruh positif dan signifikan terhadap pendapatan pengusaha industri sanggah di Kecamatan Mengwi. Apabila modal bertambah, maka pendapatan akan semakin meningkat. 
Hasil penelitian ini menunjukan bahwa modal dapat mempengaruhi pendapatan pengusaha industri sanggah di Kecamatan Mengwi. Modal dalam bentuk modal, asset atau nilai dari peralatan kerja yang digunakan dalam proses produksi mengindifikasikan dapat mempengaruhi peningkatan produksi yang dapat menyebabkan peningkatan pendapatan. Dengan tambahan modal yang cukup besar dapat membantu pengusaha industri sanggah di Kecamatan Mengwi untuk meningkatkan jumlah pendapatan yang dihasilkan. Butarbutar (2017) menyatakan bahwa modal sangat penting bagi setiap proses produksi, tanpa adanya modal maka produksi tidak akan berjalan dengan lancar. Dimana semakin tinggi modal maka pendapatan industri semakin meningkat.

Berdasarkan hasil analisis pengaruh tenaga kerja terhadap pendapatan diperoleh nilai Signifikansi sebesar 0,002 <0,05 dengan $t_{\text {hitung }}=3,182>1,674$. Hal ini berarti bahwa tenaga kerja secara parsial berpengaruh positif dan signifikan terhadap pendapatan pengusaha industri sanggah di Kecamatan Mengwi. Apabila tenaga kerja bertambah, maka pendapatan akan semakin meningkat.

Faktor tenaga kerja berpengaruh terhadap pendapatan pengusaha industri sanggah di Kecamatan Mengwi, berarti bahwa jumlah tenaga kerja yang digunakan dalam proses produksi sanggah memberikan dampak yang signifikan terhadap naik atau turunnya pendapatan yang diperoleh pengusaha industri sanggah di Kecamatan Mengwi. Tenaga kerja merupakan faktor yang sangat penting dalam produksi, karena tenaga kerja merupakan faktor penggerak faktor input yang lain, tanpa adanya tenaga kerja maka faktor produksi lain tidak akan 
Komang Widya Nayaka, Pengaruh Modal, Tenaga Kerja dan Bahan Baku...

berarti. Dengan meningkatnya produktifitas tenaga kerja akan mendorong peningkatan produksi sehingga pendapatan pun akan ikut meningkat. Youriyah (2007) menyatakan bahwa tenaga kerja berpengaruh secara positif terhadap pendapatan. Apabila tenaga kerja mengalami peningkatkan produktivitas maka dapat memenuhi permintaan konsumen sehingga dengan demikian pendapatan akan meningkat.

Berdasarkan hasil analisis pengaruh bahan baku terhadap pendapatan diperoleh nilai Signifikansi sebesar 0,003 $<0,05$ dengan $t_{\text {hitung }}=3,159>1,674$. Bahan baku secara parsial berpengaruh positif dan signifikan terhadap pendapatan pengusaha industri sanggah di Kecamatan Mengwi. Apabila bahan baku bertambah, maka pendapatan akan semakin meningkat.

Bahan baku juga merupakan faktor penting yang mempengaruhi pendapatan. Semakin besar jumlah bahan baku yang dimiliki, maka semakin besar pula kemungkinan jumlah produk yang dihasilkan, sehingga kemungkinan pendapatan yang diterima semakin besar dari hasil penjualan produksinya. Suartawan dan Purbadharmaja (2017) menyatakan bahwa bahan baku merupakan faktor produksi yang dibutuhkan dalam proses produksi. Persediaan bahan baku di dalam perusahaan merupakan hal yang sangat penting untuk dikendalikan dengan baik, sehingga dapat menghasilkan pendapatan yang optimal.

Hasil uji asumsi klasik yang dilakukan dalam penelitian ini adalah uji normalitas, uji multikoliniearitas, uji autokorelasi dan uji heteroskedastisitas. Hasil dari uji asumsi klasik yang diolah dengan bantuan software SPSS 18.0 disajikan sebagai berikut. 
Tabel 14 Hasil Uji Normalitas

\begin{tabular}{cc}
\hline & Unstandardized Residual \\
\hline $\mathbf{N}$ & 57 \\
\hline Kolmogorov-Smirnov $\mathbf{Z}$ & 0,511 \\
\hline Asymp.Sig.(2-tailed) & 0,957
\end{tabular}

Sumber: Data Primer Diolah, 2017.

Berdasarkan Tabel 14 dapat dilihat bahwa nilai Kolmogorov Sminarnov (K-S) sebesar 0,511, sedangkan nilai Asymp. Sig. (2-tailed) sebesar 0,957. Hasil tersebut mengindikasikan bahwa model persamaan regresi tersebut berdistribusi normal karena nilai Asymp. Sig. (2-tailed) 0,957 lebih dari nilai alpha 0,05. Oleh karena itu model yang dibaut pantas digunakan untuk analisis lebih lanjut.

Tabel 15 Hasil Uji Multikoleniaritas

\begin{tabular}{ccc}
\hline Variabel & Tolerance & VIF \\
\hline Modal $\left(\mathbf{X}_{\mathbf{1}}\right)$ & 0,700 & 1,428 \\
\hline Tenaga Kerja $\left(\mathbf{X}_{\mathbf{2}}\right)$ & 0,771 & 1,296 \\
\hline Bahan Baku $\left(\mathbf{X}_{\mathbf{3}}\right)$ & 0,721 & 1,388
\end{tabular}

Sumber: Data Primer Diolah, 2017.

Berdasarkan Tabel 15 dapat dilihat bahwa nilai tolerance dan VIF untuk setiap variabel yakni modal, tenaga kerja, dan bahan baku memiliki nilai tolerance yang lebih besar dari $10 \%$ dan nilai VIF lebih kecil dari 10 yang berarti model persamaan regresi bebas dari multikolinearitas. Hal ini menunjukan bahwa tidak ada gejala multikolinieritas dari model regresi yang dibuat, sehingga model tersebut layak digunakan untuk memprediksi. 
Komang Widya Nayaka, Pengaruh Modal, Tenaga Kerja dan Bahan Baku...

Tabel 16 Hasil Uji Heteroskedastisitas

\begin{tabular}{|c|c|c|c|c|c|c|}
\hline \multirow{2}{*}{\multicolumn{2}{|c|}{ Model }} & \multicolumn{2}{|c|}{$\begin{array}{l}\text { Unstandardized } \\
\text { Coefficients }\end{array}$} & \multirow{2}{*}{$\begin{array}{c}\text { Standardized } \\
\text { Coefficients } \\
\text { Beta }\end{array}$} & \multirow{2}{*}{$\tau$} & \multirow[b]{2}{*}{ Sig. } \\
\hline & & $\mathrm{B}$ & Std. Error & & & \\
\hline \multirow[t]{4}{*}{1} & (Constant) & 3.221 & 1.431 & & 2.251 & .029 \\
\hline & Modal & -.068 & .096 & -.110 & -.701 & .486 \\
\hline & Tenaga Kerja & .018 & .069 & .038 & .255 & .800 \\
\hline & Bahan Baku & -.119 & .075 & -.244 & -1.582 & .120 \\
\hline
\end{tabular}

Sumber: Data Primer Diolah, 2017.

Pada tabel 16 dapat dilihat bahwa nilai signifikansi dari variabel modal, tenaga kerja dan bahan baku masing - masing memiliki nilai sebesar 0,486; 0,800 dan 0,120. Nilai tersebut lebih besar dari 0,05 yang berarti tidak terdapat pengaruh antara variabel bebas terhadap absolute residual. Dengan demikian, model yang dibuat tidak mengandung gejala heteroskedastisitas, sehingga layak digunakan untuk memprediksi.

\section{Pembahasan Hasil Penelitian}

Hasil analisis menunjukkan bahwa Modal berpengaruh positif dan signifikan terhadap Pendapatan. Hal ini memiliki makna bahwa semakin tinggi Modal, maka akan semakin tinggi pula pendapatan pengusaha industri sanggah di Kecamatan Mengwi. Begitu pula sebaliknya, semakin rendah Modal, maka akan semakin rendah pula pendapatan yang diperoleh pengusaha industri sanggah di Kecamatan Mengwi. Menurut Manurung (2007), dalam membangun sebuah bisnis dibutuhkan sebuah dana atau dikenal dengan modal. Bisnis yang dibangun tidak akan berkembang tanpa didukung dengan modal, sehingga modal dapat dikatakan menjadi jantungnya bisnis yang dibangun tersebut. Maka dari itu, adanya modal akan mempengaruhi pendapatan yang akan diterima. Modal dengan 
kuantitas yang besar dapat memberikan peluang jumlah keuntungan yang besar pula dibandingkan dengan keadaan jumlah modal yang relatif kecil (Bhagas, 2016). Apabila modal meningkat maka produksi akan meningkat sehingga dapat meningkatkan pendapatan (Fachrizal, 2016).

Penelitian ini mendukung beberapa hasil penelitian sebelumnya dan konsisten dengan hasil penelitian Sulistiana dan Soesatyo (2013), Priyandika (2015), Adhiatma (2014), Butarbutar (2017), Utami (2013), Revathy (2016), Danendra (2016), Ridha dan Putri (2017), Adhiatma (2015), Suartawan dan Purbadharmaja (2017), Saputra (2013), Putro (2014), Candora dan Patnasari (2013), Normansyah (2015), Putri dan Jember (2016) yang memperoleh hasil bahwa modal berpengaruh positif dan signifikan terhadap pendapatan.

Hasil analisis menunjukkan bahwa tenaga kerja berpengaruh positif dan signifikan terhadap pendapatan. Hal ini memiliki makna bahwa semakin banyak Tenaga Kerja yang digunakan, maka akan semakin tinggi Pendapatan yang dapat diperoleh. Begitu pula sebaliknya, semakin sedikit tenaga kerja yang digunakan, maka akan semakin rendah Pendapatan yang diperoleh pengusaha industri sanggah di Kecamatan Mengwi. Hal ini menunjukkan bahwa tenaga kerja merupakan faktor yang sangat penting dalam produksi, karena tenaga kerja merupakan faktor penggerak faktor input yang lain, tanpa adanya tenaga kerja maka faktor produksi lain tidak akan berarti. Dengan meningkatnya produktifitas tenaga kerja akan mendorong peningkatan produksi sehingga pendapatan pun akan ikut meningkat. Hasil penelitian ini sesuai dengan hasil penelitian Youriyah (2007) yang menyatakan bahwa tenaga kerja berpengaruh secara positif terhadap 
Komang Widya Nayaka, Pengaruh Modal, Tenaga Kerja dan Bahan Baku...

pendapatan. Artinya, apabila tenaga kerja mengalami peningkatkan produktivitas maka dapat memenuhi permintaan konsumen sehingga dengan demikian pendapatan akan meningkat. Penelitian ini mendukung beberapa hasil penelitian sebelumnya dan konsisten dengan hasil penelitian Ridha dan Putri (2017), Malik, dkk. (2017), Bhagas (2016), Dewi (2012), Novitri (2015) dan Suryati (2017) yang memperoleh hasil bahwa Tenaga Kerja berpengaruh positif dan signifikan terhadap Pendapatan.

Hasil analisis menunjukkan bahwa bahan baku berpengaruh positif dan signifikan terhadap Pendapatan. Hal ini memiliki makna bahwa semakin banyak Bahan Baku yang disediakan, maka akan semakin tinggi pendapatan yang diperoleh pengusaha industri sanggah di Kecamatan Mengwi. Begitu pula sebaliknya, semakin sedikit bahan baku yang digunakan, maka akan semakin tinggi pendapatan yang diperoleh pengusaha industri sanggah di Kecamatan Mengwi. Hasil tersebut mengindikasikan bahwa bahan baku juga merupakan faktor penting yang mempengaruhi pendapatan. Semakin besar jumlah bahan baku yang dimiliki, maka semakin besar pula kemungkinan jumlah produk yang dihasilkan, sehingga kemungkinan pendapatan yang diterima semakin besar dari hasil penjualan produksinya. Penelitian ini mendukung beberapa hasil penelitian sebelumnya dan konsisten dengan hasil penelitian Ridha dan Putri (2017), Malik, dkk. (2017), Panjaitan (2011), Putro (2014), Novitri (2015) dan Puspitasari (2012) yang memperoleh hasil bahwa bahan baku secara parsial memiliki pengaruh yang positif terhadap pendapatan. 


\section{SIMPULAN DAN SARAN}

Simpulan yang dapat diambil berdasarkan hasil analisis dan pembahasan adalah modal, tenaga kerja, dan bahan baku secara simultan berpengaruh signifikan terhadap Pendapatan pengusaha industri sanggah di Kecamatan Mengwi. Selain itu, modal, tenaga kerja, dan bahan baku secara parsial berpengaruh positif dan signifikan terhadap pendapatan pengusaha industri sanggah di Kecamatan Mengwi, yaitu berarti bahwa semakin besar modal yang dikeluarkan, tenaga kerja yang digunakan dan jumlah bahan baku yang dimiliki, maka semakin besar pula kemungkinan jumlah produk yang dihasilkan, sehingga kemungkinan pendapatan yang diterima semakin besar dari hasil penjualan produksinya.

Berdasarkan hasil penelitian dan kesimpulan, maka saran-saran yang dapat diberikan yaitu pengusaha industri sanggah di Kecamatan Mengwi sebaiknya meningkatkan kapasitas produksi yaitu dengan menambah peralatan sehingga output yang dihasilkan dapat meningkat, maka untuk menambah kapasitas produksi ini dibutuhkan tambahan modal bagi pengusaha industri sanggah.

Industri sanggah di Kecamatan Mengwi belum mempunyai wadah untuk koordinasi antar pelaku usaha. Maka dari itu diharapkan adanya paguyuban, paguyuban ini akan memudahkan para pelaku usaha sanggah untuk bertukar informasi mengenai kondisi pasar, kebijakan pemerintah dan juga hal-hal yang berkaitan dengan keberlangsungan industri sanggah itu sendiri. Apabila dilihat dari sisi finansial paguyuban ini akan mempermudah pelaku usaha untuk memperoleh akses dalam proses kredit karena paguyuban akan berfungsi sebagai 
Komang Widya Nayaka, Pengaruh Modal, Tenaga Kerja dan Bahan Baku...

jaminan. Lalu dari segi perkembangan usaha paguyuban ini akan mempermudah para pelaku usaha dalam memasarkan produknya secara luas sehingga setiap pelaku usaha akan saling membantu untuk proses pengembangan industri sanggah. Pengusaha industri sanggah di Kecamatan Mengwi sebaiknya juga selalu memperhatikan keberadaan bahan baku yang dimiliki dan menjamin selalu tersedianya bahan baku yang digunakan, sehingga dapat mempercepat dan memperlancar proses produksi, yang nantinya dapat meningkatkan pendapatan.

Dalam upaya peningkatan produksi dibutuhkan sekali bantuan dari Pemerintah Kabupaten Badung baik dalam hal pelatihan atau penyuluhan untuk meningkatkan pengetahuan pengusaha dan tenaga kerja terutama dalam hal peningkatan kualitas produk. Demikian juga dalam hal pemasaran, bahwa dengan semakin berkembangnya pasar, maka diharapkan agar kualitas produk menjadi andalan dalam sasaran pengembangan produksi dengan ditambah sistem manajemen yang terorganisasi karena tingkat persaingan dunia usaha semakin ketat dan kompetitif.

\section{REFERENSI}

Adhiatma, Alfian Arif. 2015. Pengaruh Modal Awal, Lama Usaha, Dan Jam Kerja Terhadap Pendapatan Pedagang Kayu Glondong Di Kelurahan Karang Kebagusan Kabupaten Jepara. Jurnal Universitas Dian Nuswantoro. Hal: $1-10$.

Arsyad, 2003.Media Pembelajaran. Jakarta: Rajawali Pers

Asri, Marwan. 1985. Manajemen Perusahaan, Pendekatan Operasional. Yogyakarta: BPFE.

Bhagas, Arva. 2016. Analisis Pengaruh Modal, Jumlah Tenaga Kerja, Teknologi Dan Bantuan Pemerintah Terhadap Pendapatan Usaha Mikro Kecil Dan 
Menengah (Studi Kasus Umkm Sulampita Di Kota Semarang). Skripsi. Fakultas Ekonomika Dan Bisnis Universitas Diponegoro.

Candora., dan Yenny Patnasari. 2013. Analisis Faktor-Faktor Yang Mempengaruhi Pendapatan Pengrajin Batik Kayu (Kasus pada Sentra Industri Kerajinan Batik Kayu di Dusun Krebet, Desa Sendangsari, Kecamatan Pajangan, Kabupaten Bantul, Daerah Istimewa Yogyakarta tahun 2013). Jurnal Universitas Atmajaya Yogyakarta. Hal: 1-13

Danendra Putra, I Putu dan I Wayan Sudirman. 2015. Pengaruh Modal dan Tenaga Kerja Terhadap Pendapatan Dengan Lama Usaha Sebagai Variabel Moderating. E-Jurnal EP Unud. 4(9), h: 1048-1193.

Dewi, Putu Martini. 2012. Partisipasi Tenaga Kerja Perempuan dalam Meningkatkan Pendapatan Keluarga. Jurnal Ekonomi Kuantitatif Terapan. Vol. 2, No. 2, Hal: 119-124.

Edogbanya, Adejoh \& Mr. Ja'afaru G. Sule. 2013. Revenue Generation: It's Impact on Government Developmental Effort (A Study of Selected Local Council in Kogi East Senatorial District). Global Journal of Management and Business Research Administration and Management. 13(4), pp: 12-26.

Etherington,D. M. 2006. The Indonesia Tea Industri. Bulletin Of Indonesian Economic Scale, Vol. 10 No. 2.

Fachrizal, Riza. 2016. Pengaruh Modal Dan Tenaga Kerja Terhadap Produksi Industri Kerajinan Kulit Di Kabupaten Merauke. Jurnal Ilmiah agribisnis dan Perikanan (agrikan UMMU-Ternate). Vol. 9. No. 2, Hal: 66-75

Frabdorf, Anna., Markus M. Grabka, and Johannes Schwarze . 2008. The Impact of Household Capital Income on Income Inequality: A Factor Decomposition Analysis for Great Britain, Germany and the USA. Journal of IZA. No. 3492, Pp: 1-26.

Hae-Young Lee, Jongsung Kim and Beom Cheol Cin. 2013. Empirical Analysis on the Determinants of Income Inequality in Korea. International Journal of Advanced Science and Technology. 53, pp: 95-110.

Hapsari, Pradnya Paramita. (2014). Pengaruh Pertumbuhan Usaha Kecil Menengah (UKM) terhadap Pertumbuhan Ekonomi Daerah (Studi di Pemerintah Kota Batu). Skripsi. Universitas Brawijaya. 
Komang Widya Nayaka, Pengaruh Modal, Tenaga Kerja dan Bahan Baku...

Kurniawan, Jarot. Dilema Pendidikan dan Pendapatan di Kabupaten Grobogan. Jurnal Ekonomi Kuantitatif Terapan, [S.1.], july 2016. ISSN 2303-0186. Available at: <https://ojs.unud.ac.id/index.php/jekt/article/view/22756>. Date accessed: 18 sep. 2017

Malik, Shintami Rouwelvia., Antara, Made,. dan Sulaeman. 2017. Faktor-Faktor Yang Memengaruhi Pendapatan Industri Bawang Goreng Di Kota Palu. Journal Agroland. Vol: 24, No. 1, Hal : 36 - 48

Manurung, Adler Haymans. 2008. Modal Untuk Bisnis UKM. Jakarta: Buku Kompas.

Nasution, 2002. Metode Research : Penelitian Ilmiah, Jakarta, PT. Bumi Aksara.

Ningsih, Ni Made Cahya; Indrajaya, I Gst. Bagus. Pengaruh Modal Dan Tingkat Upah Terhadap Nilai Produksi Serta Penyerapan Tenaga Kerja Pada Industri ALLO, Albertus Girik. Liberalisasi Keuangan Dan Pembangunan Ekonomi: Belajar Dari Krisis Ekonomi Kerajinan Perak. Jurnal Ekonomi Kuantitatif Terapan, [S.1.], nov. 2015. ISSN 2303-0186. Available at: <https://ojs.unud.ac.id/index.php/jekt/article/view/16499>. Date accessed: 18 sep. 2017.

Normansyah. 2015. Pengaruh Pemberian Kredit, Dan Modal Awal Terhadap Pendapatan Usaha Mikro Dan Kecil (Studi Pada Debitur Kredit Usaha Rakyat Bankrakyat Indonesia (Persero), Tbk Cabang Unit Koba Bangka Tengah). Naskah Publikasi. Fakultas Ekonomi Universitas Bangka Belitung.

Novitri, Irma Amalia. 2015. Pengaruh Tenaga Kerja Dan Bahan Baku Terhadap Peningkatan Hasil Produksi Pada Industri Tempe (Studi Kasus di Desa Bojongsari Kabupaten Indramayu). Skripsi. Institut Agama Islam Negeri (Iain) Syekh Nurjati Cirebon.

Ofori George, 2006. Construction industry and economic growth in Singapore. Bulletin os Indonesia Economic Studies. Vol 6. Issue 1.

Panjaitan, Christina. 2011. Pengaruh Biaya Bahan Baku, Bahan Penolong, Tenaga Kerja Dan Peralatan Terhadap Pendapatan Peternak Sapi Perah Kecamatan Getasan Kabupaten Semarang. Skripsi. Fakultas Ekonomi Universitas Negeri Semarang.

Parinduri, Rasyad A. 2016. Family Hardship and The Growth Of Micro And Small Firms In Indonesia. Bulletin of Indonesian Economic Studies. 50(1), pp: 53-73. 
Priyandika, Akhbar Nurseta. 2015. Analisis Pengaruh Jarak, Lama Usaha, Modal, Dan Jam Kerja Terhadap Pendapatan Pedagang Kaki Limakonveksi (Studi Kasus Di Kelurahan Purwodinatan Kota Semarang). Skripsi. Universitas Diponogoro Semarang.

Puspitasari, Andita Dian. 2012. Analisis Pengaruh Modal, Tenaga Kerja dan Bahan Baku Terhadap Keuntungan Pada Pengusaha Batik di Kampung Batik Kauman Surakarta. Skripsi. Fakultas Ekonomi Universitas Sebelas Maret Surakarta.

Putri, Ni Made Dwi Maharani., dan Jember, I Made. 2016. Pengaruh Modal Sendiri dan Lokasi Usaha Terhadap Pendapatan Usaha Mikro Kecil Menengah (UMKM) di Kabupaten Tabanan (Modal Pinjaman sebagai Variabel Intervening). Jurnal Ekonomi Kuantitatif Terapan Vol. 9 No. 2. Hal:142-150.

Pratiwi, Ayu Manik dan Yuliarmi, Nyoman. 2014. Analisis Efisiensi dan Produktivitas Industri Besar dan Sedang di Wilayah Provinsi Bali (Pendekatan Stochastic Frontier Analysis). Jurnal Ekonomi Kuantitatif Terapan. Vol. 7 No.1.

Putro, Eko Afriyanto. 2014. Analisis Efisiensi Modal, Tenaga Kerja Dan Bahan Baku Pada Industri Kecil Dan Strategi Peningkatan Pendapatan Usaha (Studi Pada Sentra Industri Mebel Tunjungsekar Kota Malang). Jurnal Ilmiah Fakultas Ekonomi Dan Bisnis Universitas Brawijaya. Hal:1-26.

Revathy, S. and V.Santhi. 2016. Impact Of Capital Structure On Profitability Of Manufacturing Companies In India. International Journal of Advanced Engineering Technology. 7(1), pp: 24-28.

Ridha, Ahmad. 2017. Faktor-Faktor Yang Mempengaruhi Pendapatan Usaha Kerajinan Tas Aceh Di Desa Ulee Madon Kecamatan Muara Batu Kabupaten Aceh Utara. Jurnal Samudra Ekonomika, Vol.1, No. 1, Hal:8793.

Siswanta, Lilik. 2011. Analisis Faktor Faktor Yang Mempengaruhi Pendapatan Perajin Genteng (Studi kasus pada industri kerajinan genteng di ceper Klaten ). Akmenika UPY. Vol. 7. Hal: 74-88.

Suartawan, I Komang., dan Purbadharmaja, I.B. 2017. Pengaruh Modal Dan Bahan Baku Terhadap Pendapatan Melalui Produksi Pengrajin Patung Kayu Di Kecamatan Sukawati Kabupaten Gianyar. E-Jurnal EP Unud, Vol. 6 No. 9. Hal : 1628-1657 
Komang Widya Nayaka, Pengaruh Modal, Tenaga Kerja dan Bahan Baku...

Sulistiana, Septi Dwi. dan Soesatyo, Yoyok. 2013. Pengaruh Jumlah Tenaga Kerja dan Modal Terhadap Hasil Produksi Industri Kecil Sepatu dan Sandal Di Desa Sambrito Kecamatan Sooko Kabupaten Mojokerto. Jurnal Ekonomi Pembangunan Fakultas Ekonomi Universitas Negeri Surabaya. Vol 1, No 3, Hal:1-18.

Sumarsono, Sonny. 2013. Ekonomi Sumber Daya Manusia Teori dan Kebijakan Publik. Jogyakarta : Graha Ilmu.

Widodo. 2005. Peran Sektor Informal di Indonesia. Pusat Studi Ekonomi dan Kebiajakn Publik (PSEKP). Yogyakarta : Universitas Gajah Mada

Youriyah, Enny. 2007. Pengaruh Modal, Tenaga Kerja, dan Lama Usaha Terhadap Pengusaha Tempe Kedelai di Desa Jatiguwi Kecamatan Sumberpucung Kabupaten Malang. Skripsi. Fakultas Ekonomi Universitas Jember.

Zhou Gideon and Madhikeni Alouis. 2013. Systems, Processes and Challenges of Public Revenue Collection in Zimbabwe. American International Journal of Contemporary Research. 3(2), pp: 49-60. 